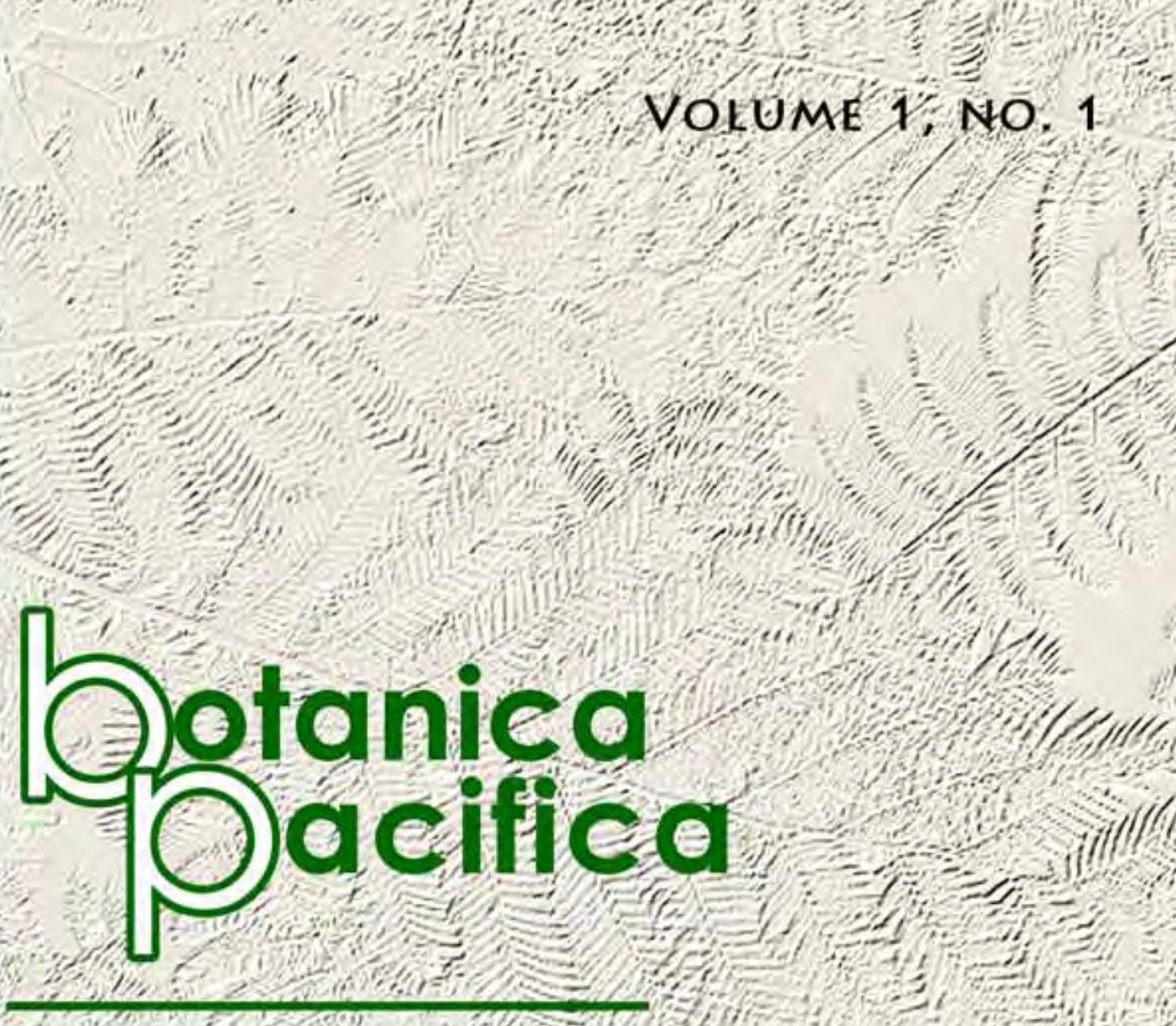

A journal of plant SCIENCE AND CONSERVATION

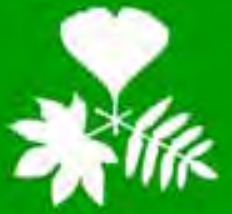

BOTANICAL GARDEN-INSTITUTE FEB RAS

*

INSTITUTE OF BIOLOGY AND

SOIL SCIENCE FEB RAS

WWW.CEOBOTANICA.RU/BP

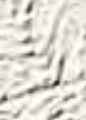

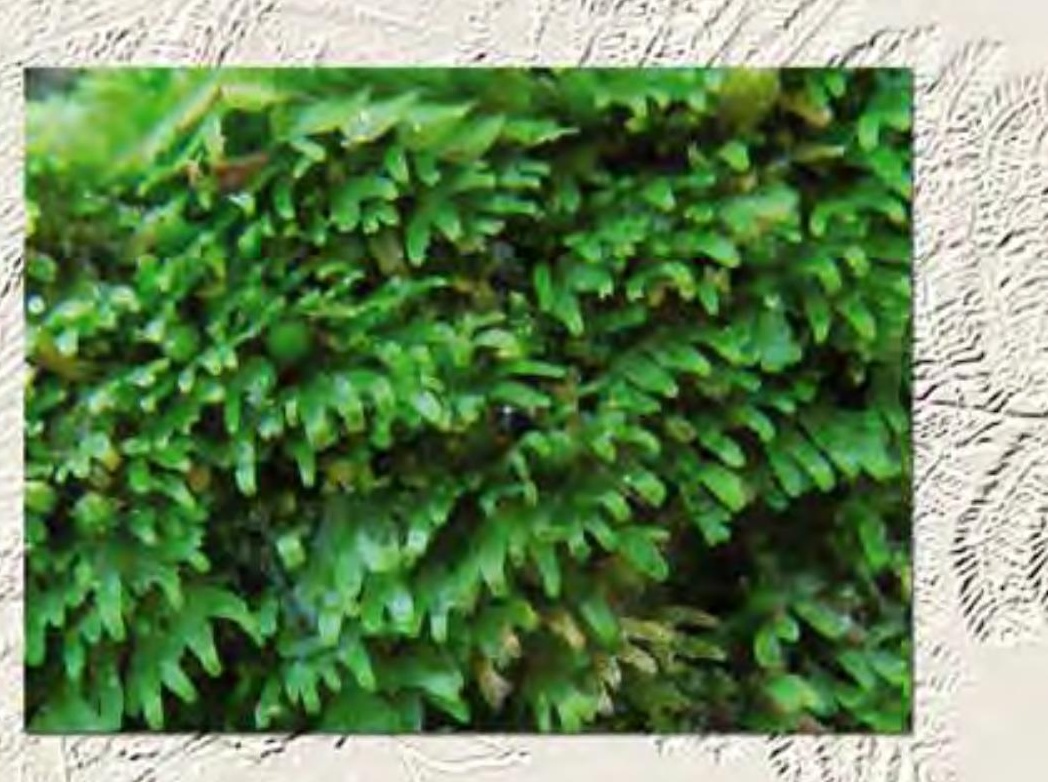




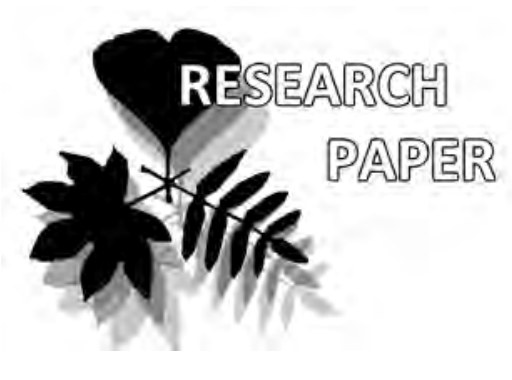

Andrew N. Gillison

Center for Biodiversity Management P.O. Box 120

Yungaburra, Queensland, 4884 Australia

E-mail: andyg@cbmglobe.org

Corresponding author

Manuscript received: 10.05.2012

Review completed: 18.06.2012

Accepted for publication: 15.07.2012

Supplementary electronic information: http://www.geobotanica.ru/bp/2012_01

\section{Circumboreal Gradients in Plant Species and Functional Types}

\author{
Andrew N. GILLISON
}

\begin{abstract}
A B S T R A C T
Questions: 1) Do patterns of richness and composition of vascular plant species and plant functional types (PFTs) vary consistently along environmental gradients in high northern latitudes? 2) What factors influence their distribution? 3) Are there implications for mapping and managing vegetation?

Location: Circumglobal $40^{\circ}$ to $70^{\circ} \mathrm{N}$.

Methods: A standard sampling protocol was used to record vegetation in $111(40 \times 5 \mathrm{~m})$ transects focusing on the circumboreal zone but within a broader environmental context including Arctic Fjaeldmark and tundra, upland continental and maritime meadows, coastal dunes, desert steppe, boreal shrubland and notthern temperate broadleaf-conifer forest. Variables included vascular plant species and PFTs (functional modi), vegetation structure, plant functional complexity (PFC) Shannon and Simpson's (functional) diversity indices and site physical features including key climate elements. Multidimensional scaling (MDS) and standard regression analysis were used to explore regional vegetation gradients.

Results: Highest counts of species, PFTs, PFC, and functional diversity indices were recorded in the Russian Far East. Most intensive clustering was revealed through MDS of species composition whereas analyses of species-weighted PFTs revealed broader overlapping gradients linking Fennoscandia and western Europe with north America. Central Mongolian sites were clearly separate from those in the Russian Far East that overlapped with central Europe and the high Caucasus. PFT-based data showed more significant linkages with vegetation structure and climate variables than species or individual traits.

Conclusions: Species and PFT-based data provide complementary support for the existence of identifiable vegetation gradients within the circumboreal zone. Apart from floristic evolutionary factors, vegetation response to disturbance and substrate appears to be secondary to climate as the primary environmental determinant. Unified systematic sampling and readily transferable technology are needed to better understand the complex factors influencing vegetation patterns in these high latitudes.
\end{abstract}

Keywords:

circumboreal gradients, plant functional types, uniform sampling protocol

\section{Гимлисон Э.Н. Циркумбореальные градиенты видов растений и функциональных типов}

Вопросы: 1) Закономерны ми изменения спектров видового состава и функциональных типов сосудистых растений вдоль экологических градиентов в высоких северных широтах? 2) Какие факторы влияют на их распределение? 3) Возможно Аи применение Аанных закономерностей Аля отображения растительного покрова?

Географическая привязка: В пределах широт от $40^{\circ}$ Ао $70^{\circ} \mathrm{N}$.

Методы: стандартные геоботанические описания растительности на 111 (40×5 м) трансектах в циркумбореальной зоне. В качестве переменных использованы виды сосудистых растений и функциональные типы растений (ФТР), структура растительности, индексы сложности структуры растительного покрова, индексы разнообразия Шеннона и Симпсона, физические характеристики местообитаний, включая ключевые параметры климата. Многомерное шкалирование (MDS) и станАартный регрессионный анализ были использованы Аля изучения региональных градиентов растительности.

Результаты: Наибольшие показатели видового богатства, ФТР и разнообразия функциональных параметров было отмечено на российском Аальнем Востоке. КАастеризация по видовому богатству получена по методу многомерного шкалирования. Анализ спектров ФТР показал сильные связи Фенноскандии и ЗапаАной Европы с Северной Америкой. Районы Центральной Монголии отличаются от российского Аальнего Востока, спектр ФТР которого оказался сходным с таковым центральной Европы и высокогорного Кавказа. ФТР проявляют более тесные связи со структурой растительности и климатическими переменными, чем видой состав и видовое богатство.

Выводы: Виды и ФТР представляют дополнительный инструмент Аля идентификации градиентов растительности в циркумбореальный зоне. Помимо флористических и эволюционных факторов, кАимат является основным детерминантом распределения растительного покрова, а реакция растительности на суб̆страт или экзогенные факторы выходит на второй план. Методика систематического отбора проб и несложная техника сбора Аанных позволяет мучше понять факторы, оказывающие влияние на закономерности распределения растительности в высоких широтах. (Переведено редколлегией).

Ключевые слова:

циркумбореальные градиенты, функциональный тип растений, универсальный протокол сбора Аанных 


\section{INTRODUCTION}

A lack of uniformity in vegetation description and data collection across the circumboreal region and its adjacent vegetation zones inhibits broadscale comparison of vegetation along key environmental gradients. Throughout the high northern latitudes confusion surrounds the delimitation of vegetation zones (Sjörs 1963, Ahti et al. 1968, Brandt 2009, Talbot \& Meades 2011). The problem is partly semantic; the meaning of such terms as 'taiga' and 'boreal' being blurred by the different usages of geographers, climatologists, and phytosociologists (Bradley et al. 1982). Despite numerous efforts to resolve classification issues, there is general recognition that even a partial solution requires a more extensive and systematic inventory and documentation than exists at present, almost certainly including cryptogamic plants and lichenized fungi ( $c f$. Ahti et al. 1968, Walker et al. 2005a, b). Most broad zonal vegetation classifications in the circumpolar, circumboreal and high latitude temperate regions are based on varying traditional physiognomic and Holdridge-type life zone criteria that tend to be applied differently across northwestern Europe, Siberia and north America. In north America the boundaries of the boreal biome tend to follow Brandt (2009), whereas Eurasian boundaries tend to follow the Map of the Natural Vegetation of Europe (Bohn et al. 2003) and the Geobotanical Map of USSR (Lavrenko \& Sochava) (see Talbot \& Meades 2011). Classification of vegetation zones and their sections in northwestern Europe by Ahti et al. (1968) recognised parallels between horizontal (latitudinal) and altitudinal pattern in vegetation types that led to the inclusion of isolated mountain ranges beyond the generally accepted circumboreal boundaries of the time (see also Hämet-Ahti 1979, 1981). A more comprehensive bioclimatic extension (Rivas-Martínez et al. 1999, Nakamura et al. 2007, Krestov \& Nakamura 2007) describes a three-dimensional vegetation distribution by zones, continentality sectors and elevation belts. Despite these advances, the need for a universal system in zonal vegetation classification is widely recognized (CAFF 2011 in Talbot \& Meades 2011) as systems are being continually modified by new information from geographically separate although similar bioclimates. A synthetic, uniform and integrated approach requires among other things, access to a methodology that facilitates data collection, data analysis and improved communication between practitioners. This paper examines the potential of one methodology for facilitating comparative studies in these northern latitudes. While bioclimatic influences are clearly significant, this paper focuses on a complementary approach to vegetation characterization using adaptive vegetation features to identify key patterns of vegetation and environmental relationships that extend beyond traditional physiognomic and floristic criteria.

Circumboreal and circumpolar regions are typically characterised by low species richness and endemism (Red Book of Russian Federation 2008, Olson \& Dinerstein 1998). In mapping terrestrial ecoregions, Olson et al. (2001) found delineation varied only slightly in boreal and polar habitats, thus facilitating ecoregional classification. Within regions and sub-regions, intensive syntaxonomic studies across the northern high latitudes now generate much more detailed phytosociological information than ever before about the distribution of taxa and community structure (Krestov 2003, Qian et al. 2003a, b, Krestov et al. 2006, Nakamura et al. 2007, Ermakov \& Morozova 2011). While regionally useful, these and other similar studies across the boreal zone are raising new questions about the universality of current vegetation classifications and whether circumboreal and circumpolar regions are as homogeneous as previously thought.

Clearly scale and purpose must drive methodological approaches where much depends on the type of classificatory units and the scale at which they are applied. Although commonly supported by physiognomy and structure, species remain the most common currency for vegetation classification. Species-based surveys can provide useful local and sub-regional information but their utility decreases with distance from site. As a result, the use of surrogate taxa for biodiversity surveys while potentially useful (Lewandowski et al. 2010) is limited at biome level and according to Bugmann (1996), impacts of climatic change on ecosystems over large areas cannot be usually assessed on a species basis.

The geographic extent of high latitude vegetation and the evident need for uniform methods of documentation place extraordinary demands on practitioners and institutional resources alike. Classification approaches tend to be polarised between two very different operational purposes and scales where, on the one hand, classifications at biome scale necessarily rely on broad physiognomic and life-zone categories based on available, usually minimal data from wide-ranging sources (cf Olson et al. 2001). On the other hand, to satisfy taxonomic and ecological purposes at landscape level, far more detailed phytosociological and other types of ecological surveys are required. The former is prone to significant information loss and the latter inevitably committed to more extensive, intensive and costly data acquisition if data are to be compared at biome level. Thus it is useful to consider whether other types of relatively low cost vegetation survey using readily transferable methodology could be employed to complement existing data and improve understanding of vegetation pattern and process at both biome and landscape scales. It is here that rapid field documentation techniques developed for hyper-rich, tropical, ombrophilous forested landscapes may have a role to play in less diverse habitats. Recent decades have seen a rapid rise in the application of plant functional types (PFTs) as a means of either replacing or complementing often problematic, species-based vegetation classification. Definitions of PFTs are many and varied (Díaz \& Cabido 1997, Gillison 2012), with perhaps the best known being 'sets of species showing similar responses to the environment and similar effects on ecosystem functioning' (Smith et al. 1992). PFTs have the potential to link ecophysiological traits with ecosystem processes at large scales (Chapin 1993, 2003, Box, 1996, 1981, Gillison 2002, 2012) and facilitate comparisons of adaptive vegetation characteristics, for example between geographically remote areas where environments and functional types may be similar but where taxa differ. Disdavantages are evident in the lack of consensus in the application of functional traits across environmental scales.

A globally applicable set of PFTs originally proposed by Box $(1996,1981)$ used pheno-physiognomic criteria to classify PFTs according to major aspects of plant function, metabolism and water balance to explore how vegetation was constrained 
by climate. The seminal work by Box set the scene for an increased focus on functional ecology of different plant growth forms in the boreal and Arctic regions, notably on carbon sequestration and water fluxes (Brooks et al. 1997), productivity, transpiration and nutrient cycling by commonly used growth forms (Chapin et al. 1996, Chapin 2003) and root distribution and function (Jackson et al. 1996, Craine et al. 2001). At biome scale, most current models of the impact of environmental change parameterize vegetation based on relatively crude ecophysiognomic growth forms such as 'grass' or 'evergreenneedle-leafed trees' (Baldocchi et al. 2000; Harrison \& Prentice 2003, Kaplan et al. 2003, Sitch et al. 2003, Hickler et al. 2004; Oleson et al. 2010). Peppe et al. (2011) on the other hand show that, compared to ecophysiognomic growth forms, models can be improved by the inclusion of leaf traits that are functionally linked to climate. Questions remain nonetheless, about the relative value of single versus multiple functional traits. Using data from the Alaskan tundra, Eviner \& Chapin (2003) proposed a theoretical functional matrix that builds upon functional group and single trait approaches to account for the ecosystem effects of multiple traits that vary independently among species. While potentially useful, at biome scale, acquisition of such detailed information is limited by the lack of cost-effective methodology that is both capable of documenting both functional traits and their biophysical habitat as well as being testable across wideranging environments.

This paper briefly describes a method of rapid survey that can be used to acquire fine scale, landscape and biome-relevant information about species, plant functional types, vegetation structure and key site physical data across all vegetation types using minimal resources. It is applied here to illustrate how such data may be readily analyzed to explore vegetation patterning at biome scale - in this case with a focus on the circumboreal zone but within the context of environmental gradients from Arctic to north temperate zones.

\section{MATERIALS AND METHODS}

The VegClass system (Gillison 2002) was used to record a uniform set of biophysical attributes that include all vascular plant species, PFTs, vegetation structure and key site physical variables (Table 1). A series of $111(40 \times 5 \mathrm{~m})$ transects (Fig. 1) was selected from a global database of more than 1800 transects each sampled using the same VegClass protocol. Except in species-rich sites where plants were densely packed, small or structurally cryptic such as alpine meadows, most transects were recorded by two observers in one hour or less. Within the circumboreal zone, forested sites tend to dominate sampling and to ignore subsidiary vegetation patterns and disturbance gradients. Yet transitional gradients between vegetation types provide important foci for both management and research. For this reason and in order to provide an appropriate ecological context for analyzing regional patterning across all vegetation, sites were purposely selected to include as wide a range of vegetation types as possible including Icelandic Fjaeldmark, Artic tundra, high elevation maritime and continental meadows, coastal dunes, Arctic and boreal shrublands and forests and continental desert steppe. For convenience, forested sites in northern Mongolia close to the Russian border were included in the Russian Far East as they supported typical Russian Taiga as distinct from grass and shrub steppe in the adjacent Mongolian Gobi desert. In certain remote locations where species identification was problematic, taxa were allocated to morpho-species whereas all other variables including PFTs were recorded using a uniform classification system outlined below. Unlike PFT classifications based on single traits or growth forms, the VegClass system is based on a whole-plant, multiple-trait approach in which an individual is composed of elements of a photosynthetic 'envelope' supported by a modified Raunkiærean life-form and an aboveground rooting system (see Box 1). This particular type of PFT is referred to as a functional modus or modal PFT (Gillison \& Carpenter 1997, Gillison 2012) and from this point onwards in this paper is referred to simply as a 'PFT'. As well as species, PFTs and vegetation structure, I included measures of plant functional complexity (PFC), Shannon's (evenness) and Simpson's inverse (1-D) (dominance) diversity indices based on abundance of species per PFT. Climate data (mean an-
Box 1. Plant Functional Typology - the Functional Modus

In the VegClass system, a plant individual is descibed as a Plant Functional Type (PFT) by combining a specific set of Plant Functional Elements (PFEs). In this treatment (see also Gillison 2012) the resultant combination is referred to as a functional modus to identify it from other PFT descriptions. A generic set of 36 PFEs is used via a rule set and grammar as a basis for describing a plant according to one or more of its functional leaf attributes, life-form and above-ground rooting system. Thus an individual of the deciduous tree species Betula ermanii might have the modal PFT mi-pedo-de-ct-ph that is composed of the PFEs microphyll leaf size class, pendulous leaf inclination, dorsiventral leaf, deciduous, ct green stem cortex, phanerophyte life form.

Within the same species a change in any one PFE (such as leaf size class, or tree to shrub) results in a different PFT. This method confers greater sensitivity in detecting change in a species along an environmental gradient, e.g. deep to shallow soils. The system comprises many-to-many mapping whereby more than one modal PFT can be represented within a species and vice versa. While $\sim 7.2$ million combinations are theoretically possible, a global dataset of $\sim 1,800$ sites indicates the 'real' number of unique modal PFTs and approximates 3,500 for the world's estimated 300,000 vascular plant species. The system is generic and can be applied uniformly to vegetation worldwide. As such it can facilitate informed and quantitative comparisions for example, between geographically remote but similar environments where PFTs are similar but where taxa differ. When combined with species data PFTs can become a potentially powerful tool in identifying indicators for biodiversity and agricultural productivity (Gillison et al. 2003). Measures of diversity are widespread in plant ecology but there are few effective measures of functional diversity. An alternative measurement of plant functional complexity (PFC) has been found especially useful as a biodiversity indicator. PFCs are calculated as a measure of the total distance of a minimum-spanning-tree of PFT distances within any one plot. The measure can differentiate between two plots which, for example, may have the same number of PFTs but very different component PFEs - and thus different measures of complexity. VegClass is supported by public domain software capable of storing original field data and generating on-demand, meta-data summaries as well as within and between plot and PFT distance matrices and a PFC measure. The package can generate Shannon, Simpson and Fisher's a diversity indices per plot based on species abundances per PFT.

The methodology is readily transferable. More information can be found in www.cbmglobe.org 
Gillison

Table 1. List of Data Variables Recorded for Each $40 \times 5 \mathrm{~m}$ Transect*

\begin{tabular}{|c|c|c|}
\hline Site feature & Descriptor & Data type \\
\hline \multirow{4}{*}{ Location reference } & Location & Alpha-numeric \\
\hline & Date (dd-mm-year) & Alpha-numeric \\
\hline & Plot number (unique) & Alpha-numeric \\
\hline & Country & Text \\
\hline Observer/s & Observer/s by name & Text \\
\hline \multirow{10}{*}{ Physical } & Latitude deg.min.sec. or decimal deg. (GPS) & Alpha-numeric \\
\hline & Longitude deg.min.sec. or decimal deg. (GPS) & Alpha-numeric \\
\hline & Elevation (m.a.s.l.) (aneroid or GPS) & Numeric \\
\hline & Aspect (compass. deg.) (perpendicular to plot) & Numeric \\
\hline & Slope percent (perpendicular to plot) & Numeric \\
\hline & Soil depth $(\mathrm{cm})$ & Numeric \\
\hline & Soil type (US Soil taxonomy preferred) & Text \\
\hline & Parent rock type & Text \\
\hline & Litter depth $(\mathrm{cm})$ & Numeric \\
\hline & Terrain position & Text \\
\hline Site history & General description and land-use / landscape context & Text \\
\hline \multirow{9}{*}{ Vegetation structure } & Vegetation type & Text \\
\hline & Mean canopy height $(\mathrm{m})$ & Numeric \\
\hline & Canopy cover percent (total) & Numeric \\
\hline & Canopy cover percent (woody) & Numeric \\
\hline & Canopy cover percent (non-woody) & Numeric \\
\hline & Cover-abundance (Domin) - bryophytes & Numeric \\
\hline & Cover-abundance woody plants $<2 \mathrm{~m}$ tall & Numeric \\
\hline & Furcation index (mean and cv \% of 20$)$ & Numeric \\
\hline & Profile sketch of $40 \times 5 \mathrm{~m}$ plot (scannable) & Digital \\
\hline \multirow{5}{*}{ Plant taxa } & Family & Text \\
\hline & Genus & Text \\
\hline & Species & Text \\
\hline & Botanical authority & Text \\
\hline & If exotic (binary, presence-absence) & Numeric \\
\hline Plant Functional Type & Constructed from plant functional elements according to rule set and grammar & Text \\
\hline Quadrat listing & Unique taxa and PFTs per quadrat (for each of $8(5 \times 5 \mathrm{~m})$ or more quadrats) & Numeric \\
\hline Photograph & Hard copy and digital image & JPEG \\
\hline
\end{tabular}

*Modified from Gillison (2002). All data are compiled in the VegClass program using the same structure as the field proforma. Methodology is generic and can be applied to any size transect and/or number of internal quadrats.

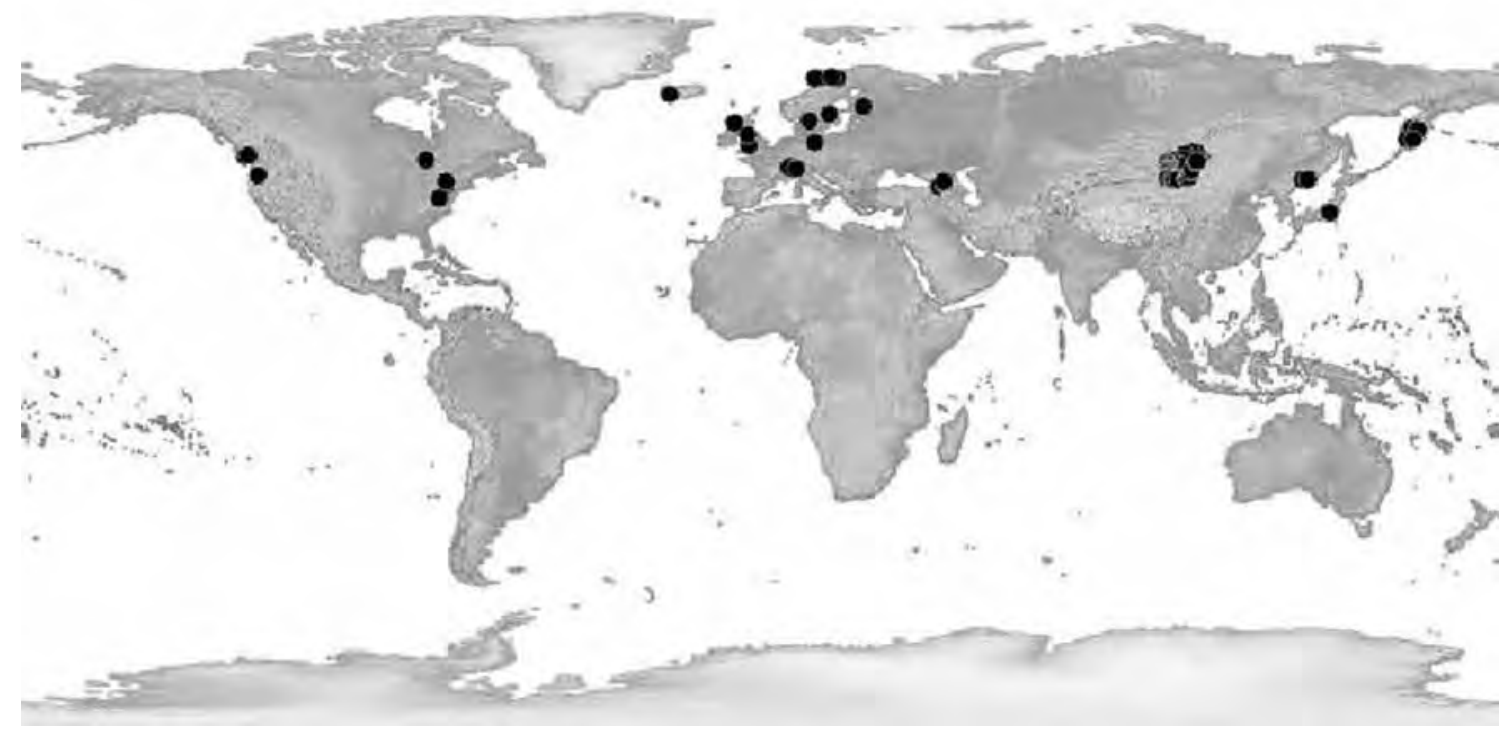

Figure 1 Location of 111 transects across the study area. 
nual precipitation, mean minimum monthy temperature and annual total actual evapotranspiration (ATET)) were extracted from public domain global climate surfaces.

With the exception of extensive detailed species and PFT listings, (accessible through the TRY database http://www.try-db.org), data analysed in this treatment are available in supplementary electronic information (Tables S 1-4). Scatter diagrams were used to detect site patterning through taxonomic and functional relationships (species richness and composition, PFTs, PFC, Shannon and Simpson). Standard Pearson correlation was used to explore relationships between taxonomic, functional attributes, diversity indices, vegetation structure and climate variables. Classification (Bray Curtis association with flexible agglomerative hierarchical fusion using the Unweighted Pair Group Method with Arithmetic Mean and multidimensional scaling (MDS) were undertaken to detect any underlying trends in regional patterning based on species-weighted PFT counts (number of species per PFT) per transect. Depending on the purpose of the analysis and the nature of the data, MDS may be applied using metric or non-metric (NMDS) algorithms, both of which exhibit strengths and weaknesses (see also Thessler et al. 2005 for NMDS relating floristic to remotely-sensed data). In the present case the PATN multivariate software package was applied using a two-dimensional semi-strong hybrid scaling (SSH) procedure (Belbin 1991, 2008). SSH maximizes the advantages of both MDS procedures by allowing combinations of non-metric (ordinal or monotone), or metric (ratio) scaling. In the present treatment only the first of two MDS axes scores was used in analyses as this axis accounted for most variance in the data.

\section{RESULTS}

A total of 1554 individual species including morphospecies was recorded as well as 483 unique (non-species connected) PFTs. For reasons of space, classification dendrograms are not shown, preference being given to gradient analysis that carried more readily interpretable information. Scatter diagrams of species richness against PFT richness and PFC values per transect (Figs. 2 and 3 respectively) show an increasing trend towards highest values in the Russian Far East and the high central Caucasus. When measured against species richness, both Simpson and Shannon diversity indices exhibit a strong curvilinear response (Figs. 4, 5), again indicating increasing diversity towards northeast Asia but with least values associated mainly with grass and shrub steppe in the more extreme thermal and moisture regimes of the Mongolian Gobi desert. Multidimensional scaling of 483 unique PFTs (Fig. 6) reflects similar gradients but with greater clarity revealing an association of Fennoscandian and north American sites. Sites from eastern Siberia and the high Caucasus showed considerable overlap but with subregional separation between Kamchatka, Primorsky region and northern Mongolia. Mongolian desert steppe and arid shrubland are clearly separated from all sites.

The MDS of species composition (Fig. 7) exhibits a more conspicuous two-dimensional clustering across the study region showing distinct trends (explained in the figure

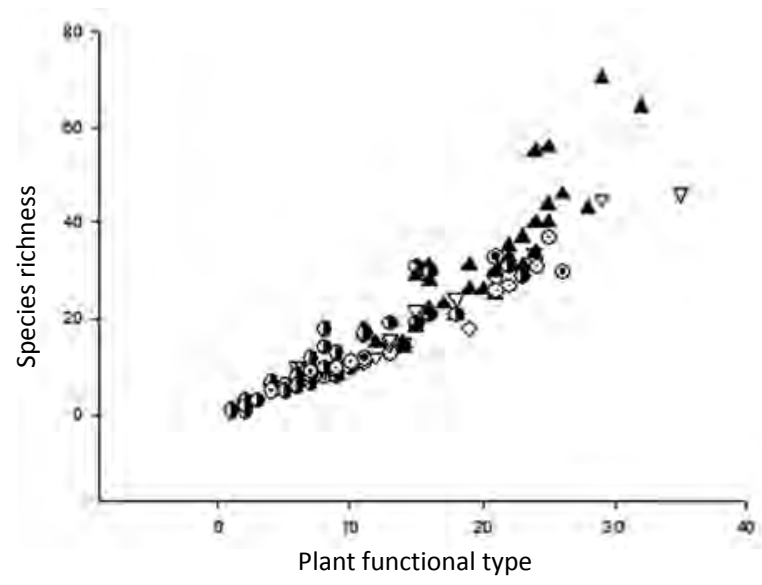

Figure 2 Relative richness in vascular plant species and PFTs across all vegetation types. Legend: Russian Far East and Northern Mongolia (Solid triangle); Central Mongolia (semi-filled circle); Central Europe and Caucasus (inverted open triangle); Fennoscandia (circle with cross); North America (dotted circle); Western Europe and UK (open diamond); Japan (triangle with cross). Each point represents a $40 \times 5 \mathrm{~m}$ transect.

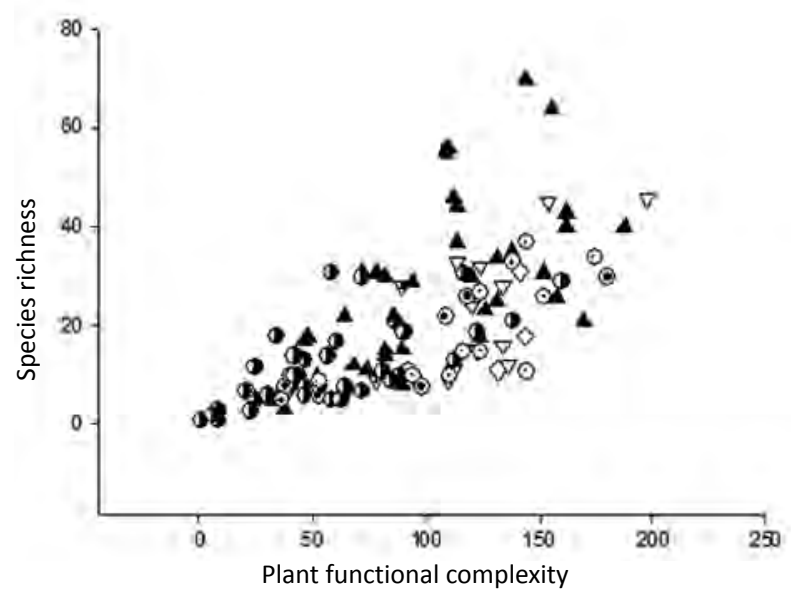

Figure 3 Pattern of vascular plant species and plant functional complexity (PFC) across all vegetation types. Legend: See Fig. 2.

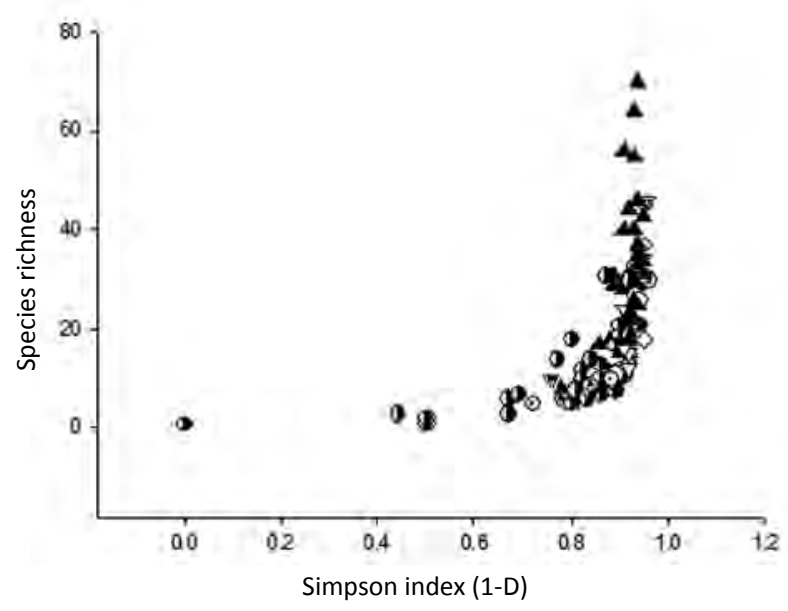

Figure 4 Species richness and Simpson's diversity (1-D) index across all vegetation types. For legend see Fig. 2. 


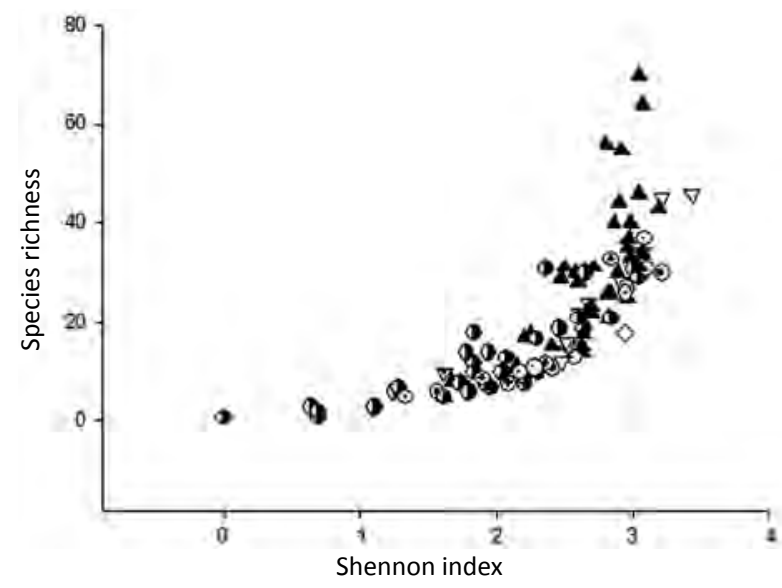

Figure 5 Species richness and Shannon-Weiner $\mathrm{H}^{\prime}$ diversity index for all vegetation types. For legend see Fig. 2.

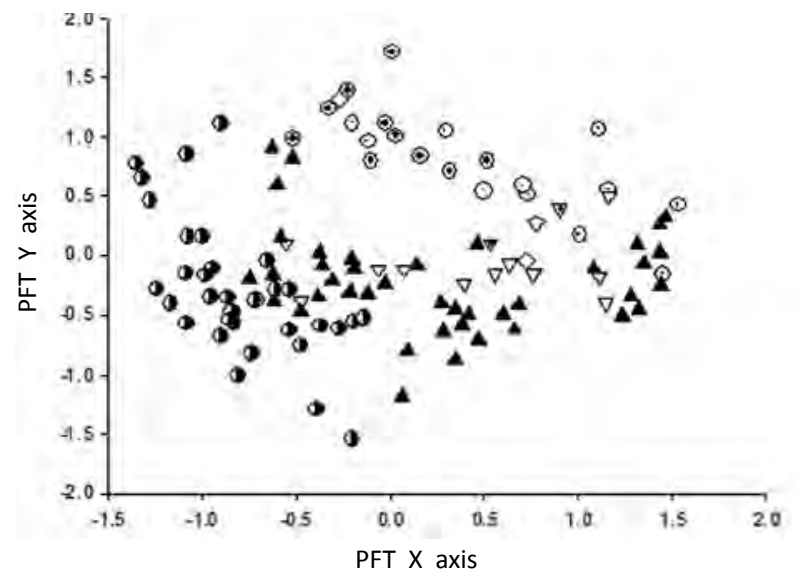

Figure 6 Multidimensional scaling across all vegetation types based on all species-weighted, unique modal PFTs. Legend: See Fig. 2.

legend). Correlations between individual traits and species richness were highly variable, the most significant being microphyll leaf size class that typifies circumboreal trees and shrubs. Overall, when matched against species richness and composition and individual traits, PFTs were more informative in detecting regional patterns. Of a number of single functional traits (PFEs) that also contributed to site clustering, the microphyll trait was most consistent overall. A highly linear relationship between microphyll counts and species richness (Fig. 8) illustrates the constancy between these two variables. However, microphyll counts matched against an MDS of species composition (Fig. 9) revealed a much clearer set of regional clusters. A range of statistically significant correlations existed between values derived from species and plant functional data and key elements of vegetation structure (mean canopy height, projective canopy cover, basal area, litter depth, bryophyte cover-abundance) (Table 2). Of these, the most significant predictors of vegetation structure were PFC and PFT MDS scores. Compared with vegetation structure, correlation with climate values were relatively weak, again with a marginally significant correlation between PFT MDS and ATET. More informative patterning is evident when PFT MDS is matched graphically against ATET, minimum temperature and mean annual precipitation (Figs. 10-12). Patterns of richness between PFTs, species and these three climate variables can be seen in the supplementary electronic material (Figs. S1 a, b; S2 a, b; S3 a, b).

\section{DISCUSSION}

These results are the product of very limited sampling over a very large area. Considered together with problems in species identification at a number of sites, outcomes should therefore be viewed with some caution. Sampling limitations are nonetheless offset to some degree by the relative homogeneity in plant diversity at high latitudes when compared to more heterogeneous, biodiverse equatorial regions that attract far more intensive sampling. Notwithstanding sampling issues, there are some obvious trends where, for example, the distribution pattern of modal PFTs in this treatment is consistent with known vegetation response to environment elsewhere (Gillison 2012). This together with some obvious correspondence between PFTs and climate variables, tends to support the existence of functional linkages between vegetation and climate identified in this paper. The trend is not inconsistent with evidence from North Korea (Šrůtek et al. 2003) where, although relatively little variation in species composition is explained by ordination, environmental gradients were recognizeable in both mountain coniferous forests and in mixed pine-oak forests. The selection of plant functional characteristics for general classification purposes is influenced by a continuing debate surrounding the predictive potential of single versus multiple traits as environmental or biodiversity indicators. On the one hand, many ecologists ( $c f$. Wardle et al. 1998, Westoby 1998, Wright et al. 2004) argue individual traits such as specific leaf area, function independently from others. Elsewhere it has been argued that traits which strongly covary over environmental gradients can vary independently across scales, for example in the Alaskan tundra (Eviner \& Chapin 2003). More recent evidence suggests however, that such traits may not operate in functional isolation, their performance being modulated by other important elements such as leaf inclination, longevity and life form. One may therefore speculate that, depending on their composition, trait assemblages will be subject to complex functional feedbacks that will vary according to environment and evolutionary background (Chapin 2003, Posada et al. 2009, Gillison 2012). The challenge is to identify and combine functional traits in a way that can be applied meaningfully in science and in practice.

Phenotypic variation within and between species is frequently manifested along environmental gradients of light, moisture and nutrient availability. Whereas this information is rarely contained in a species name, within the same taxon it may be captured by appropriately constructed PFTs. An illustration of how single traits vary in combination within the same taxon is presented in Table 3 where the genus Betula, recorded across seven countries, exhibited infrageneric and infraspecific variation in trait combinations. This variation reflects differences in habitat, for example where changes in leaf size class and green 
stem photosynthesis were consistent with corresponding changes in ambient temperature and preciptiation. When considered independently from PFTs, certain individual traits such as microphyll leaf size, are closely correlated with species richness (Fig. 8). When matched against MDS of species composition, almost all individual traits produce a clear separation of sites in the Primorsky region but with less distinct zonation elsewhere (Fig. 9). Overall, site clustering is much less apparent and less interpretable with individual traits than with PFTs (Fig. 6), suggesting that trait combinations may be more appropriate than individual traits when exploring evidence for vegetation zonation.

At landscape and continental scales, PFTs using combined traits allow a more readily interpretable pattern of vegetation response along environmental gradients than broad physiognomic units such as 'evergreen broadleaf-conifer'. While useful for broadscale geographic purposes, at community level the latter typology runs the risk of masking ecological information that is vital to understanding vegetation dynamics. To be able to predict vegetation response to environmental change requires tools that enable effective monitoring of plant response along readily measureable biophysical gradients, the data acquired should facilitate scaling up from plot to biome and assist vegetation mapping the desired scale. In more biodiverse equatorial vegetation (Gillison 2002, Gillison et al. 2004) PFTs are know to be sensitive indicators of disturbance (i.e. loss of tissue or taxa) and as such can be used to both identify and monitor disturbance impacts on biodiversity and related agro-productivity. In the present study almost all sites were impacted in some way, typically by grazing, fire, logging or agriculture or in extreme cases as natural vulcanoseres as in the Uzon caldera in Kamchatka. Grazing is an important and relatively little studied environmental factor in the region (cf. Zemmrich 2010) and grazed pastures and meadows for example in the high Caucasus and Kamchatka exhibited similarities in PFT response as well as Betula-dominated Krummholz in exposed sites, contributing in part to identifying ecological features common to both the Russian Far East and the high continental Caucasus.

The results of this study appear to be generally consistent with known overlaps in composition of genera and species north and south of the boreal zone that are, for example, illustrated in an analysis of northeast Asia (Russian Far East, NE China, N part of Korean peninsula and Hokkaido island (Japan)) which, according to Qian et al. (2003a), shares $39 \%$ of its species with eastern Siberia-Mongolia, 24\% with Europe, 16.2\% with northwest America and 12.4\% with northeast America. The northernmost (Arctic) region shares $64 \%$ of its genera and $9 \%$ of its species with the southernmost (warm termperate) region. The Russian Far East (an area of about 3 million square kilometers) contains natural vegetation ecosystems from polar deserts to cooltemperate forests, from the Pacific coast to the continental interior (Krestov 2003). It seems possible therefore that the relatively high plant diversity recorded in the Primorsky subregion may be due in part to the conjoint influence of maritime and continental climate (see also Hämet-Ahti 1981) on overlapping types of oceanic and continental Be-

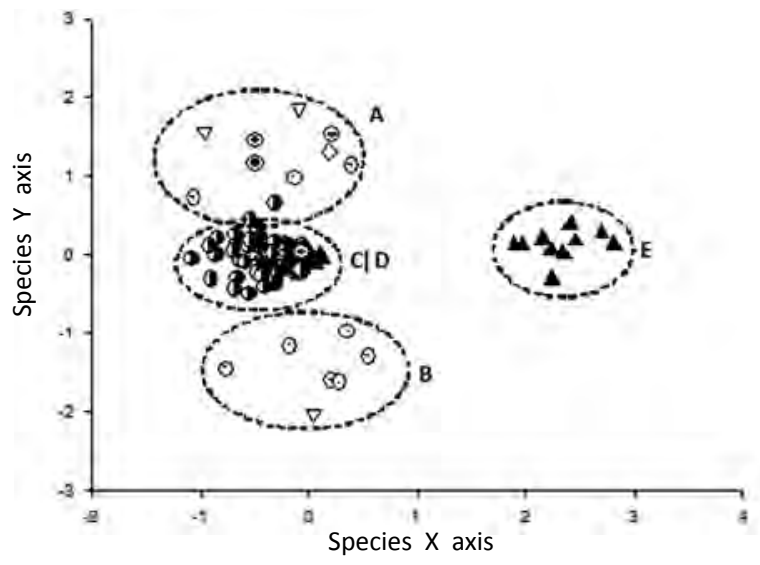

Figure 7 Multidimensional scaling across all vegetation types based 1554 vascular plant species. Legend: See Fig. 2. See main text for comment on group structure.

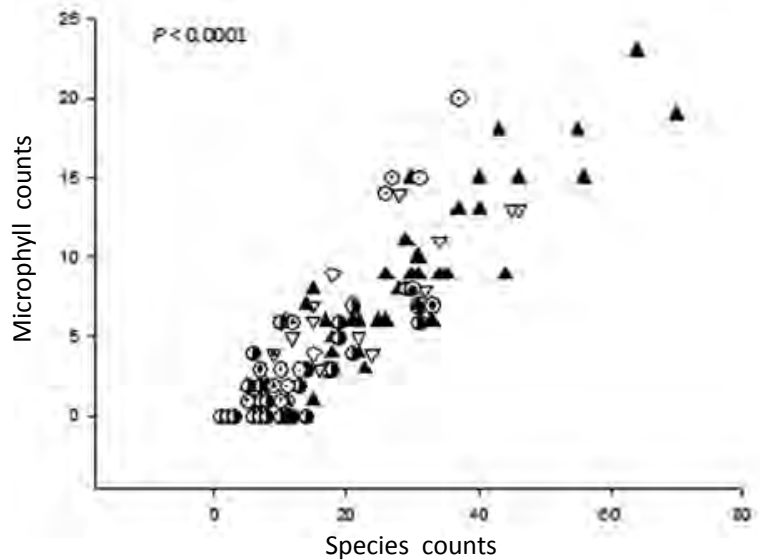

Figure 8 Relationship between species richness and microphyll counts across all transects. Despite the highly significant linear correlation, delimitation of regional site groups is much less than with PFTs or species composition. Legend: see Fig. 2.

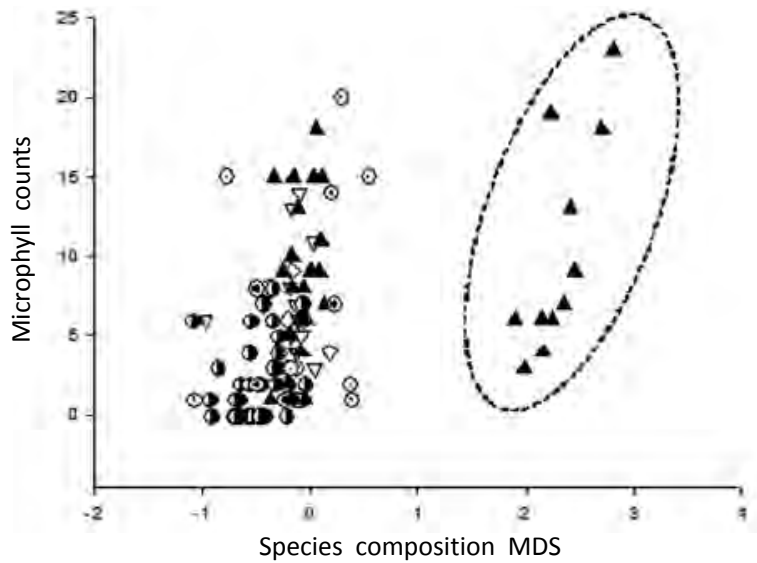

Figure 9 Species composition MDS (first axis) against microphyll counts reveals separation of all sites from the Primorsky region of the Russian Far East (cluster with dashed line).

tula woodlands). The separation of higher elevation Kamchatkan sites (Arctic tundra) and their overlap with those of the high Caucasus appears to be due on the one hand to similar influences of temperature and wind exposure (cf. Šrůtek et al. 2003 for N. Korean mountain forests) but also to grazing impact - such influences being reflected in PFTs 
Table 2. Correlation Between Species, PFTs and Derived Values Against Vegetation Structure and Climate Variables

\begin{tabular}{|c|c|c|c|c|c|c|c|}
\hline Variable* & Spp & PFT & PFC & Shannon index & Simpson index & PFT MDS & Spp MDS \\
\hline Height & $\begin{array}{l}0.189 \\
0.047\end{array}$ & $\begin{array}{l}0.301 \\
0.001\end{array}$ & $\begin{array}{l}0.510 \\
0.000\end{array}$ & $\begin{array}{l}0.398 \\
0.000\end{array}$ & $\begin{array}{l}0.340 \\
0.000\end{array}$ & $\begin{array}{l}0.768 \\
0.000\end{array}$ & $\begin{array}{l}0.421 \\
0.000\end{array}$ \\
\hline CC total & $\begin{array}{l}0.469 \\
0.000\end{array}$ & $\begin{array}{l}0.501 \\
0.000\end{array}$ & $\begin{array}{l}0.462 \\
0.000\end{array}$ & $\begin{array}{l}0.535 \\
0.000 \\
\end{array}$ & $\begin{array}{l}0.461 \\
0.000 \\
\end{array}$ & $\begin{array}{l}0.374 \\
0.000 \\
\end{array}$ & $\begin{array}{l}0.292 \\
0.002 \\
\end{array}$ \\
\hline CC woody $(\%)$ & $\begin{array}{l}0.359 \\
0.000\end{array}$ & $\begin{array}{l}0.409 \\
0.000\end{array}$ & $\begin{array}{l}0.462 \\
0.000\end{array}$ & $\begin{array}{l}0.424 \\
0.000\end{array}$ & $\begin{array}{l}0.307 \\
0.003\end{array}$ & $\begin{array}{l}0.714 \\
0.000\end{array}$ & $\begin{array}{l}0.572 \\
0.000\end{array}$ \\
\hline CC non-woody & $\begin{array}{c}0.051 \\
\text { n.s. }\end{array}$ & $\begin{array}{c}0.059 \\
\text { n.s. }\end{array}$ & $\begin{array}{l}0.489 \\
0.000 \\
\end{array}$ & $\begin{array}{c}0.102 \\
\text { n.s. }\end{array}$ & $\begin{array}{c}0.158 \\
\text { n.s. }\end{array}$ & $\begin{array}{c}-0.265 \\
0.010\end{array}$ & $\begin{array}{c}-0.326 \\
0.001\end{array}$ \\
\hline $\mathrm{BA}$ & $\begin{array}{l}0.189 \\
0.047\end{array}$ & $\begin{array}{l}0.300 \\
0.001\end{array}$ & $\begin{array}{l}0.522 \\
0.000\end{array}$ & $\begin{array}{l}0.382 \\
0.000\end{array}$ & $\begin{array}{l}0.325 \\
0.001\end{array}$ & $\begin{array}{l}0.819 \\
0.000\end{array}$ & $\begin{array}{l}0.476 \\
0.000\end{array}$ \\
\hline Litt. Dpth & $\begin{array}{l}0.315 \\
0.001\end{array}$ & $\begin{array}{l}0.407 \\
0.000\end{array}$ & $\begin{array}{l}0.511 \\
0.000\end{array}$ & $\begin{array}{l}0.453 \\
0.000\end{array}$ & $\begin{array}{l}0.348 \\
0.000\end{array}$ & $\begin{array}{l}0.601 \\
0.000 \\
\end{array}$ & $\begin{array}{l}0.394 \\
0.000 \\
\end{array}$ \\
\hline Bryophyte cov. abund. & $\begin{array}{c}0.141 \\
\text { n.s. }\end{array}$ & $\begin{array}{l}0.232 \\
0.014\end{array}$ & $\begin{array}{l}0.293 \\
0.002\end{array}$ & $\begin{array}{l}0.267 \\
0.005\end{array}$ & $\begin{array}{c}0.159 \\
\text { n.s. }\end{array}$ & $\begin{array}{l}0.277 \\
0.003\end{array}$ & $\begin{array}{c}0.142 \\
\text { n.s. }\end{array}$ \\
\hline Mean Precip. & $\begin{array}{c}0.083 \\
\text { n.s. }\end{array}$ & $\begin{array}{c}0.164 \\
\text { n.s. }\end{array}$ & $\begin{array}{l}0.319 \\
0.001\end{array}$ & $\begin{array}{l}0.247 \\
0.011\end{array}$ & $\begin{array}{l}0.263 \\
0.007\end{array}$ & $\begin{array}{l}0.588 \\
0.000\end{array}$ & $\begin{array}{c}0.109 \\
\text { n.s. }\end{array}$ \\
\hline Min. Tmp. & $\begin{array}{c}-0.030 \\
\text { n.s. }\end{array}$ & $\begin{array}{c}0.086 \\
\text { n.s. }\end{array}$ & $\begin{array}{l}0.325 \\
0.001\end{array}$ & $\begin{array}{c}0.161 \\
\text { n.s. }\end{array}$ & $\begin{array}{c}0.145 \\
\text { n.s. }\end{array}$ & $\begin{array}{l}0.620 \\
0.000 \\
\end{array}$ & $\begin{array}{l}0.201 \\
0.039 \\
\end{array}$ \\
\hline ATET & $\begin{array}{l}0.311 \\
0.002\end{array}$ & $\begin{array}{c}0.415 \\
\text { n.s. }\end{array}$ & $\begin{array}{l}0.542 \\
0.000\end{array}$ & $\begin{array}{l}0.444 \\
0.000\end{array}$ & $\begin{array}{l}0.337 \\
0.001\end{array}$ & $\begin{array}{l}0.659 \\
0.000\end{array}$ & $\begin{array}{l}0.410 \\
0.000\end{array}$ \\
\hline
\end{tabular}

*Height $=$ mean canopy height $(\mathrm{m}) ; \mathrm{CC}$ total (total projected crown cover \%); CC woody (projected crown cover $\%$ woody plants); CC non-woody (projected crown cover $\%$ non-woody plants); BA (basal area $\mathrm{m}^{2} \mathrm{ha}^{-1}$ ); Litt. Dpth. (litter depth $(\mathrm{cm})$ ); Bryophyte cov. abund. (cover abundance Domin scale). PFT MDS (first axis scores of MDS); Spp. MDS (first axis scores of MDS); Mean Precip.(mean annual precip ( $\left.\mathrm{mm} \mathrm{yr}^{-1}\right)$ ); Min Tmp. (minimum temperature coldest month (Deg C.)); ATET (Actual Total Evapotranspiration $\left(\mathrm{mm} \mathrm{yr}^{-1}\right)$ ). Upper cell is Pearson correlation, lower shaded cell is $P$ value; n.s. (not significant).

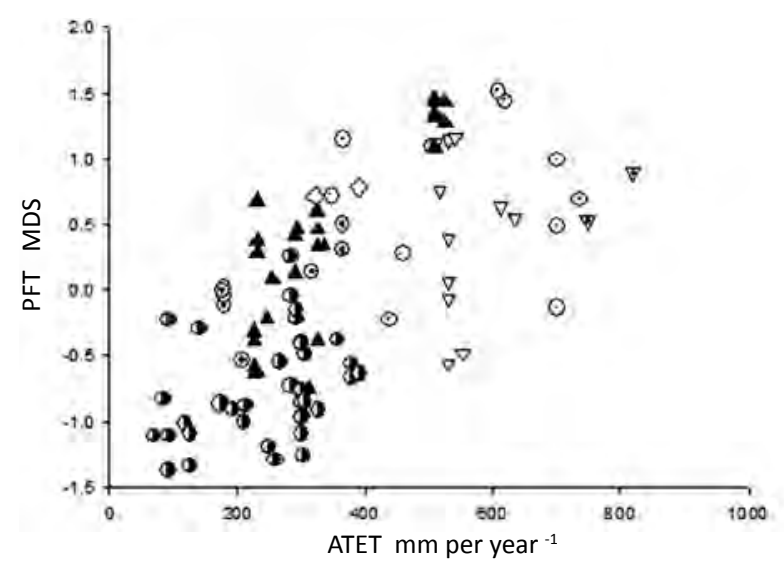

Figure 10 PFT MDS and ATET.

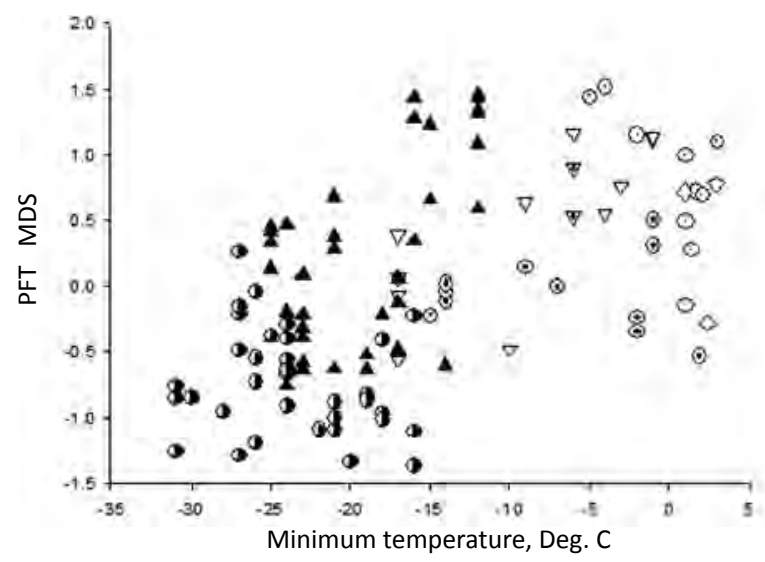

Figure 11 PFT MDS and minimum temperature. common to both areas including some closely related taxa.

The vegetation gradients identified here clearly correspond with latitude and elevation that for ecological purposes are best expressed in terms of thermal and moisture gradients. According to Krestov (2011), within the polar, boreal and temperate macroclimates that control vegetation formation, basic changes of vegetation along the continentality gradient depend on the variations of the yearly heat and precipitation distribution that are manifested through 6 continentality sectors: oceanic, suboceanic, maritime, continental, subcontinental and ultracontinental. In east Asia together with current and prior land connections, covarying elements such as temperature and precipitation are primarily responsible for observed latitudinal variation in plant adaptation (Qian et al. 2003b). Freeze and thaw dynamics influence permafrost development and paludification that in turn affects root performance, photosynthesis and other metabolic processes (cf. Vygodskaya et al. 2007) all of which are ultimately manifested in distinctive suites of functional traits. I would add that while such processes apply throughout the study area, certain historical conditions (e.g. glaciation, vulcanicity) greatly influence soil and other ecological processes as well as wind exposure and other biotic and abiotic factors (Šrůtek \& Doležal 2003; Douma et al. 2012).

A question arises as to what criteria should be selected by vegetation mappers to make the best use of information about existing vegetation gradients. While a number of approaches are being investigated towards a more unified mapping system (Talbot \& Meades 2011), Simons (2005) maintains that the map units in a boreal ecological framework must identify and accurately group broad, yet relatively homogeneous, natural vegetation types. I would add that, based on evidence in this paper, in addition to broad physiognomic and floristic elements, readily identifiable groups of PFTs or subsets of single traits such as a modified Raunkiærean life-form, and certain leaf-based traits such as size class and inclination, may provide a useful classificatory key especially where it is important to 


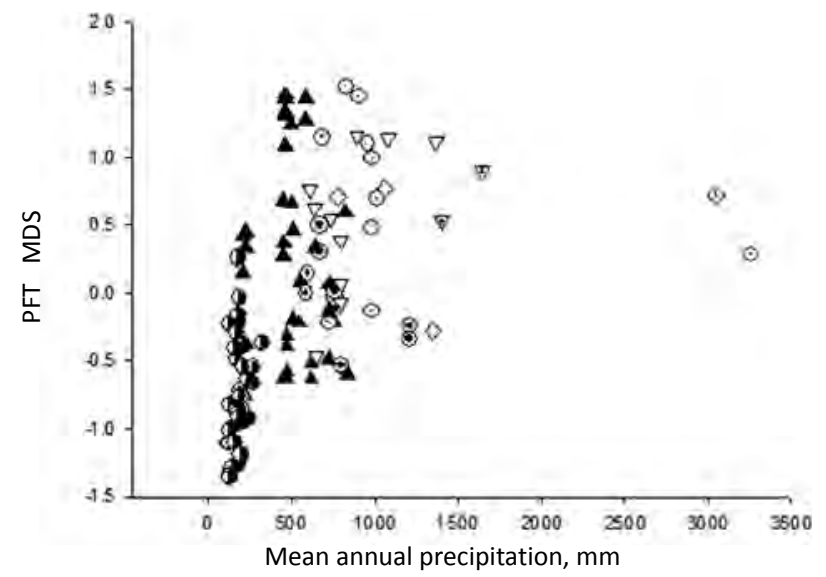

Figure 12 PFT MDS and mean annual precipitation.

identify and classify natural and man-made disturbance - significant features rarely included in mapping systems. Functional attributes of this kind also offer an opportunity to couple more meaningful ecological aspects of vegetation with remotely sensed imagery than broad physiognomy or floristics.

Throughout northern Eurasia the amplitudes of many changes in terrestrial ecosystems are among the greatest in the world. Vygodskaya et al. (2007) argue that, without an integrative approach to all major feedbacks between terrestrial ecosystems and climate, reliable projections of environmental change are impossible. The logic of this approach is indisputable. The unfortunate reality is that to meet this challenge requires detailed and costly experimentation. There may be at least a partial solution to this problem due to significant advances in ecophysiological understanding of plant adaptation to environment. These advances should facilitate more informed selection of plant functional attributes (Gillison 2012) leading to improved methods of vegetation assessment and monitoring as well

\section{LITERATURE CITED}

Ahti, T., L. Hämet-Ahti \& J. Jalas 1968. Vegetation zones and their sections in northwestern Europe. Annales Botanici Fennici 5:169-211.

Baldocchi, D., F. M. Kelliher, T. A. Black \& P. Jarvis 2000. Climate and vegetation controls on boreal zone energy exchange. Global Change Biology 6(S1):69-83.

Belbin, L. 1991. Semi-strong Hybrid Scaling, a new ordination algorithm. Journal of Vegetation Science 2(4):491-496.

Belbin, L. 2008. PATN. http://mmw.patn.com.au. Accessed 30 April 2012.

Bohn, U., G. Gollub, C. Hettwer, Z. Neuhauslova, H. Schlueter \& H. Weber 2003. Karte der natürlichen Vegetation Europas. Map of the natural vegetation of Europe. Federal Agency for Nature Conservation, Bonn.

Box, E. O. 1981. Macroclimate and plant forms: An introduction to predictive modeling in phytogeography. Tasks for Vegetation Science - 1. Dr. W. Junk, The Hague, 258 pp.

Box, E. O. 1996. Plant functional types and climate at the global scale. Journal of Vegetation Science 7(3):309-320.
Table 3. Circumboreal Variation in Modal PFTs in the Genus Betula

\begin{tabular}{|l|c|c|c|}
\hline Species & Modal PFT & Location & Country \\
\hline Betula costata & no-co-do-de-ch & Shkotovo & Russia \\
\hline B. daurica & mi-co-do-de-ph & Shkotovo & Russia \\
\hline B. daurica & no-co-do-de-ph & Vladivostok & Russia \\
\hline B. daurica & no-la-do-de-ch & Vladivostok & Russia \\
\hline B. ermanii & mi-pe-do-de-ph & Gothenburg (cult.) & Sweden \\
\hline B. ermanii & no-co-do-de-ph & Kiyevka Pass & Russia \\
\hline B. ermanii & no-la-do-de-ch & Kamchatka & Russia \\
\hline B. ermanii & no-la-do-de-ct-ph & Kamchatka & Russia \\
\hline B. ermanii & no-pe-do-de-ct-ph & Kamchatka & Russia \\
\hline B. ermanii & no-pe-do-de-ph & Kamchatka & Russia \\
\hline B. exilis & mi-ve-do-ph & Kamchatka & Russia \\
\hline B. litwinowii & mi-la-do-de-ph & Mt Kazbegi & Georgia \\
\hline B. litwinowii & mi-pe-do-de-ct-ph & Mt Kazbegi & Georgia \\
\hline B. litwinowii & mi-pe-do-de-ph & Mt Kazbegi & Georgia \\
\hline B. nana & na-pe-do-de-ph-ad & Abisko & Sweden \\
\hline B. papyrifera & no-pe-do-de-ct-ph & Ontario & Canada \\
\hline B. pendula & mi-pe-do-de-ph & Ascona & Switzerland \\
\hline B. platyphylla & mi-co-do-de-ph & Shkotovo & Russia \\
\hline B. platyphylla & mi-co-do-de-ph & Khentii Mts & Mongolia \\
\hline B. platyphylla & mi-pe-do-de-ct-ph & Khentii Mts & Mongolia \\
\hline B. platyphylla & no-co-do-de-ph & Kamchatka & Russia \\
\hline B. platyphylla & no-ve-do-de-ph & Kamchatka & Russia \\
\hline B. playphylla & mi-pe-do-de-ct-ph & Kamchatka & Russia \\
\hline B. tortuosa & mi-pe-do-de-ph & Abisko & Sweden \\
\hline B. tortuosa & mi-pe-do-de-ph & Narvik & Norway \\
\hline B. verrucosa & mi-pe-do-de-ct-ph & Lammi & Finland \\
\hline
\end{tabular}

as predictive modeling. Increasingly integrated approaches to assessing vegetation dynamics at landscape scale already include phytosociological methods (Nakamura et al. 2007). The complementary use of functional typology at landscape scale (Liira et al. 2008, Lavorel et al. 2011) and at biome scale as indicated in this paper may provide a useful additional approach.

Bradley, S. W., J. S. Rowe \& C. Tarnocai 1982. An ecological land survey of the Lockhart River map area, Northwest Territories. In: Ecological Land Classification. Series 16. Lands Directorate, Environment Canada, Ottawa, Ontario, 150 pp.

Brandt, J. P. 2009. The extent of the North American boreal zone. Environmental Review 17(1):101-161.

Brooks, J. R., L. B. Flanagan, N. Buchmann \& J. R. Ehleringer 1997. Carbon isotope composition of boreal plants: functional grouping of life forms. Oecologia 110(3):301-311.

Bugmann, H. 1996. Functional types of trees in temperate and boreal forests: classification and testing. Journal of Vegetation Science 7(3):359-370.

Chapin, F. S. III 2003. Effects of plant traits on ecosystem and regional processes: a conceptual framework for predicting the consequences of global change. Annals of Botany 91:455-463.

Chapin, F. S. III, M. S. Bret-Harte, S. E. Hobbie \& H. Zhong 1996. Plant functional types as predictors of transient responses of Arctic vegetation to global change. Journal of Vegetation Science 7(3):347-358. 
Chapin, F. S. III 1993. Functional role of growth forms in ecosystem and global processes. In: Scaling physiological processes. Leaf to globe (J. R. Ehleringer \& C. B. Field, eds.), pp. 287-312, Academic Press, London.

Craine, J. M., D. G. Froehle, D. A. Tilman, F. S. Wedin \& F. S. Chapin III 2001. The relationships among root and leaf traits of 76 grassland species and relative abundance along fertility and disturbance gradients. Oikos 93(2):274-285.

Díaz, S. \& M. Cabido 1997. Plant functional types and ecosystem function in relation to global change. Journal of Vegetation Science $8(4): 463-474$

Douma, J. C., M. W. A. de Haan, R. Aerts, J.-P. M. Witte \& P. M. van Bodegom 2012. Succession-induced trait shifts across a wide range of NW European ecosystems are driven by light and modulated by initial abiotic conditions. Journal of Ecology $100(2): 366-380$

Ermakov, N. \& O. Morozova 2011. Syntaxonomical survey of boreal oligotrophic pine forests in northern Europe and Western Siberia. Applied Vegetation Science 14(4):524-536.

Eviner, V. T. \& F. S. Chapin III 2003. Functional matrix: a conceptual framework for predicting multiple plant effects on ecosystem processes. Annual Reviews of Ecology and Systematics 34:455485.

Gillison, A. N. \& G. Carpenter 1997. A generic plant functional attribute set and grammar for dynamic vegetation description and analysis. Functional Ecology 11(6):775-783.

Gillison, A. N. \& N. Liswanti 2004. Assessing biodiversity at landscape level: the importance of environmental context. Agriculture, Ecosystems and Environment 104:75-86.

Gillison, A. N. 2002. A generic, computer-assisted method for rapid vegetation classification and survey: tropical and temperate case studies. Conservation Ecology 6(3) [online] http://www.consecol.org/vol6/iss2/art3

Gillison, A. N. 2012. Plant functional types and traits at the com munity, ecosystem and world level. In: Vegetation Ecology (E. van der Maarel \& J. Franklin, eds.), chapter 12, Wiley-Blackwell, Oxford, $\mathrm{UK}$ (in press).

Gillison A.N., Jones D.T., Susilo F.-X. \& Bignell D.E. 2003. Vegetation indicates diversity of soil macroinvertebrates: a case study with termites along a land-use intensification gradient in lowland Sumatra. Organisms, Diversity \& Evolution 3(2): 111-126.

Hämet-Ahti, L. 1979. The dangers of using the timberline as the "zero" line in comparative studies on altitudinal vegetation zones. Phytocoenologia 6:49-54.

Hämet-Ahti, L. 1981. The boreal zone and its biotic subdivision. Fennia 159(1):69-75.

Harrison, S. P. \& I. C. Prentice 2003. Climate and CO controls on global vegetation distribution at the last glacial maximum: analysis based on palaeovegetation data, biome modelling and palaeoclimate simulations. Global Change Biology 9(7):983-1004.

Hickler, T., B. Smith, M. T. Sykes, M. B. Davis, S. Sugita \& K. Walker 2004. Using a general vegetation model to simulate vegetation dynamics in northeastern U.S.A. Ecology 85(2):519-530.

Jackson, R. B., J. Canadell, J. R. Ehleringer, H. A. Mooney, O. E. Sala \& E.-D. Schulze 1996. A global analysis of root distribution for terrestrial biomes. Oecologia 108(3):389-411.

Kaplan, J. O., N. H. Bigelow, I. C. Prentice, S. P. Harrison, P. J Bartlein, T. R. Christensen, W. Cramer, N. V. Matveyeva, A. D. McGuire, D. F. Murray, V. Y. Razzhivin, B. Smith, D. A. Walker, P. M. Anderson, A. A. Andreev, L. B. Brubaker, M. E. Edwards \& A. V. Lozhkin 2003. Climate change and Arctic ecosystems 2. Modeling, paleodata-model comparisons, and future projections. Journal of Geophysical Research 108:D19, 8171.

Krestov, P. V. \& Y. Nakamura 2007. Climatic controls of forest vegetation distribution in Northeast Asia. Berichte der ReinholdTüxen-Gesellschaft 19:131-145.
Krestov, P. V. 2003. Forest Vegetation of Easternmost Russia (Russian Far East). In: Forest vegetation of Northeast Asia (J. Kolbek et al., eds.), pp. 93-180, Kluwer Academic Publishers, Dordrecht.

Krestov, P. V., J.-S. Song, Y. Nakamura \& V. P. Verkholat 2006. A phytosociological survey of the deciduous temperate forests of mainland Northeast Asia. Phytocoenologia 36(1):77-150.

Krestov, P. V. 2011. Climatic control of eastern Russia in the Holocene. In: Northeast Asia Eco-Forum on Sustainable Development and Regional Ecological Security (Abstracts), Shenyang, China. http:/ /www. iae.cas.cn/qt/tzgg/201109/W020110920572492470881.doc

Lavorel, S., K. Grigulis, P. Lamarque, M.-P. Colace, D. Garden, J. Girel, G. Pellet \& R. Douzet 2011. Using plant functional traits to understand the landscape distribution of multiple ecosystem services. Journal of Ecology 99(1):135-147.

Lavrenko, E. M. \& V. B. Sochova (eds.) 1954. Geobotanical map of the USSR (scale 1:4 million). Komarov Botanical Institute, Leningrad (in Russian). [Геоботаническая карта СССР. 1954. Масштаб 1 : 4000000 / под реА. Аавренко Е.М. и Сочавы В.Б.]

Lewandowski, A. S., R. F. Noss \& D. R. Parsons 2010. The effectiveness of surrogate taxa for the representation of biodiversity. Conservation Biology 24(5):1367-1377.

Liira, J., T. Schmidt, T. Aavik, P. Arens, I. Augenstein, D. Bailey, R. Billeter et al. 2008. Plant functional group composition and large-scale species richness in European agricultural landscapes. Journal of Vegetation Science 19(1):3-14.

Nakamura, Y., P. V. Krestov \& A. M. Omelko 2007. Bioclimate and zonal vegetation in Northeast Asia: first approximation to an integrated study. Phytocoenologia 37(2-3):443-470.

Oleson, K. W., D. M. Lawrence, G. B. Bonan, M. G. Flanner, E. Kluzek, P. J. Lawrence, S. Levis et al. 2010. Technical Description of version 4.0 of the Community Land Model (CLM). Climate and Global Dynamics Division National Center For Atmospheric Research. Technical Note NCAR/TN-478+STR.

Olson, D. M. \& E. Dinerstein 1998. The Global 200: a representation approach to conserving the Earth's most biologically valuable ecoregions. Conservation Biology 12(3):502-515.

Olson, D. M., E. Dinerstein, E. D. Wikramanayake, N. D. Burgess, G. V. N. Powell, E. C. Underwood, J. A. D'Amico et al. 2001. Terrestrial Ecoregions of the World: A New Map of Life on Earth. BioScience 51(11):933-938.

Peppe, D. J., D. L. Royer, B. Cariglino, S. Y. Oliver, S. Newman, E. Leight, G. Enikolopov et al. 2011. Sensitivity of leaf size and shape to climate: global patterns and paleoclimatic applications. New Phytologist 190(3):724-739.

Posada, J. M., M. J. Lechowicz \& K. Kitajima 2009. Optimal photosynthetic use of light by tropical tree crowns achieved by adjustment of individual leaf angles and nitrogen content. Annals of Botany 103(5):795-805.

Qian, H., P. V. Krestov, P.-Y. Fu, Q.-L. Wang, J.-S. Song \& C. Chourmouzis 2003a. Phytogeography of Northeast Asia. In: Forest vegetation of Northeast Asia (J. Kolbek et al., eds.), pp. 51-91, Kluwer Academic Publishers, Dordrecht.

Qian, H., J.-S. Song, P. V. Krestov, Q. Guo, Z. Wu, X. Shen \& X. Guo 2003b. Large-scale phytogeographical patterns in East Asia in relation to latitudinal and climatic gradients. Journal of Biogeograpby 30(1):129-141.

Red Book of Russian Federation (Plants and Fungi). 2008. Tovarishchestvo nauchnikh izdatelstv KMK, Moscow, 855 pp. (in Russian) [Красная книга Российской Фелерации (Растения и грибы). 2008. Москва: Товарищество научных издательств КМК. 855 с.]

Rivas-Martínez, S., D. Sánchez-Mata \& M. Costa 1999. North American boreal and western temperate forest vegetation. (Syntaxonomical synopsis of the potential natural plant communities of North America,II.) Itinera Geobotanica 12:5-316. 
Simons, H. 2005. Global ecological zoning for the FAO Global Forest Resources Assessment 2000. Application and analysis of the map of the Natural Vegetation of Europe. In: Application and Analysis of the Map of the Natural Vegetation of Europe (U. Bohn, C. Hettwer \& G. Gollub, eds.), pp. 55-69, Bonn (Bundesamt für Naturschutz), BfN-Skripten.

Sitch, S., B. Smith, I. C. Prentice, A. Arneth, A. Bondeau, W. Cramer, J. O. Kaplan et al. 2003. Evaluation of ecosystem dynamics, plant geography and terrestrial carbon cycling in the LPJ Dynamic Global Vegetation Model. Global Change Biology 9(2):161-185

Sjörs, H. 1963. Amphi-Atlantic zonation, Nemoral to Arctic. In: North Atlantic Biota and Their History (Á. Löve \& D. Löve, eds.), pp. 109-125, Pergamon Press, New York.

Smith, T. M., H. H. Shugart, F. I. Woodward \& P. J. Burton 1992. Plant functional types. In: Vegetation Dynamics and Global Change (A. M. Solomon \& H. H. Shugart, eds.), pp. 272-292, Chapman \& Hall, New York, NY.

Šrůtek, M., J. Kolbek, I. Jarolímek \& M. Valachovič 2003. Vegetation-environment relationships within and among selected natural forests in North Korea. In: Forest Vegetation of Northeast Asia (J. Kolbek et al., eds.), pp. 363-382, Kluwer Academic Publishers, Dordrecht.

Talbot, S. S. \& W. J. Meades 2011. Circumboreal Vegetation Map (CBVM) - Mapping the green halo. Concept paper CAFF Strategy Series Report No. 3. http://www.iavs.org/uploads/CBVMConceptPaper.pdf

Thessler, S., K. Ruokolainen, H. Tuomisto \& E. Tomppo 2005. Mapping gradual landscape-scale floristic changes in Amazoni- an primary rain forests by combining ordination and remote sensing. Global Ecology \& Biogeography 14(4):315-325.

Vygodskaya, N. N., P. Ya. Groisman, N. M. Tchebakova, J. A. Kurbatova, O. Panfyorov, E. I. Parfenova \& A. F. Sogachev 2007. Ecosystems and climate interactions in the boreal zone of northern Eurasia. Environmental Research Letters 2(4):(045033) (1-7).

Walker, D. A., A. Elvebakk, S. S. Talbot \& F. J. A. Daniëls 2005a. The Second International Workshop on Circumpolar Vegetation Classification and Mapping: a tribute to Boris A. Yurtsev. Phytocoenologia 35(4):715-726.

Walker, D. A., M. K. Raynolds, F. J. A. Daniëls, E. Einarsson, A. Elvebakk, W. A. Gould, A. E. Katenin, S. S. Kholod, C. J. Markon, E. E. Melnikov, N. G. Moskalenko, S. S. Talbot, B. A. Yurtsev \& the CAVM Team. 2005b. The Circumpolar Arctic Vegetation Map. Journal of Vegetation Science 16(3):267-282.

Wardle, D., G. Barker, K. Bonner \& K. Nicholson 1998. Can comparative approaches based on plant ecophysiological traits predict the nature of biotic interactions and individual plant species in ecosystems? Journal of Ecology 86(3):405-420.

Westoby, M. 1998. A leaf-height-seed (LHS) plant ecology strategy scheme. Plant and Soil 199(2):213-227.

Wright, I. J., P. B. Reich, M. Westoby, D. D. Ackerly, Z. Baruch, F. Bongers, J. Cavender-Bares et al. 2004. The worldwide leaf economics spectrum. Nature 428 (6985):821-827.

Zemmrich, A. 2010. Plant communities along an elevational gradient under special consideration of grazing in western Mongolia. Phytocoenologia 40(2-3):91-115. 
